\title{
Ownership Concentration and Accounting Conservatism: Portuguese Evidence
}

\author{
Sandra Alves \\ GOVCOPP \\ School of Accountancy and Administration \\ University of Aveiro
}

\begin{abstract}
Existing literature suggest that conservatism is to related to ownership structure. The Portuguese governance structure is characterized by the dominance of the largest shareholder who typically exercises significant influences on management decisions directly or indirectly. Therefore, for a sample of 26 non-financial listed Portuguese firms-year from 2002 to 2016, we examine the association between accounting conservatism and ownership concentration. The study's results suggest that ownership concentration demand for more conservatism. The results also suggest that higher leverage and large firms have a greater demand for conservative accounting.
\end{abstract}

Keywords: Ownership Concentration, Conservatism Accounting, Corporate Governance.

\section{Introduction}

The separation of ownership and control results in information asymmetry and potential conflict of interests between management and shareholders (Jensen and Meckling 1976; Fama 1980). Agency theory suggests that the monitoring mechanisms can improve the alignment of management and shareholders' interests and mitigate any opportunistic behaviour resulting from conflict of interests. Therefore, properly structured corporate governance mechanisms are expected to provide effective monitoring of management in the financial reporting process.

Literature also suggests that conservatism benefits financial statement users by constraining managerial opportunism, mitigating agency problems associated with managerial investment decisions, and enabling efficient debt agreements in the presence of asymmetric information (Basu, 2005; Ball and Shivakumar, 2006; Ahmed and Duellman, 2007; Francis et al., 2013; Ruch and Taylor, 2014). Evidence also suggests a direct relationship between corporate governance structure and accounting practice (Ball and Shivakumar, 2006; Ahmed and Duellman, 2007; García Lara et al., 2009). For example, Ahmed and Duellman (2007) and García Lara et al. (2009) provide evidence that firms having certain governance structures engage in more conservative reporting. Chi et al. (2009) explore the relationship between accounting conservatism and corporate governance. Their results indicate that firms with weaker governance structures tend to be more conservative. Parthasarathy (2010) also finds that as the level of incentive alignment increases, financial statements are reported less conservatively. Thus, ineffective governance structures will require higher levels of conservative accounting.

Ideally, an empirical study of governance mechanisms would conduct a joint examination of the entire set of internal and external governance mechanisms that collectively maximize value. However, the identification and estimation of structural equations that jointly explain the choice of governance mechanisms is a very difficult task. We focus on the relationship between ownership concentration and accounting conservatism for two reasons.

First, conservatism has played an important role in accounting theory and practice over the past several decades. Holthausen and Watts (2001) and Watts (2003a) argue that conservatism persists because it also helps to address agency problems. In this sense, for example, LaFond and Roychowdhury (2008) and García Lara et al. (2009) suggest that accounting conservatism may serve to reduce information asymmetry between managers and shareholders and thus lessen agency costs, resulting in better protection of shareholders and firm value. This suggests that accounting conservatism plays a role as an agency deterrent and contracting mechanism.

Second, the ownership structure of a firm is considered an important managers' monitoring mechanism. Extant literature suggests that different ownership structures imply different incentives to control and monitor a firm's management (Shleifer and Vishny, 1986; Morck et al., 1988). In addition, Cullinan et al. (2012, p. 3) refer that "ownership structures vary among entities. These different ownership structures can result in variation in governance structures, which would reflect the different rights associated with various types of owners. These governance structures in turn could lead a greater or lesser degree of influence over the financial reporting process by large owners and/or managers". As a result, studying the relationship between ownership concentration and conservatism is potentially interesting. 
Using a sample of 26non-financial firms listed on Euronext Lisbon over a period of 15 years, from 2002 through 2016, we analyse the association between ownership concentration and accounting conservatism. We find that conservatism is positively related with ownership concentration. Thus, this study suggests that ownership concentration is an important source of demand for conservatism as a governance device.

This study makes some interesting contributions to the existing literature. First, it extends the corporate governance literature on ownership structures by extending the research into the effects of ownership structure on accounting conservatism beyond US and Asia environments (LaFond and Roychowdhury, 2008; Chen et al., 2009; Shuto and Takada, 2010; Cullinan et al., 2012; Ramalingegowda and Yu; 2012).

Second, we provide the first empirical evidence on the effect of ownership structure on accounting conservatism using Portuguese data. In particular, we show that there exists a tradeoff between conservatism and ownership structure in an agency setting characterized by the presence of large controlling shareholders. This feature can influence the conservatism activity, because highly concentrated ownership determines the nature of the agency problem in Portuguese firms. In fact, in firms with a concentrated ownership, there is a real danger that dominant shareholders may mistreat or expropriate minority shareholders.

Finally, this study will be important to Euronext Lisbon and other regulators, especially the Portuguese Securities Commission and Portuguese Accounting Commission, that are concerned about earnings reported and improving the quality of financial reporting, as well the transparency of financial disclosure and the ability to predict each company's future.

This paper is structured as follows. In section two, we provide an overview of the literature review and develop testable hypothesis. We present the variable measurement and research design in section three. The results are reported and discussed in section four. We provide sensitivity tests in section five. Finally, section six concludes the study.

\section{Literature Review and Testable Hypothesis}

Conflicts of interest between managers and other parties to the firm arise because managers effectively control firms' assets but generally do not have a significant equity stake in their firms (Jensen and Meckling, 1976). Corporate governance mechanisms can improve the alignment of management and shareholders' interests and mitigate any opportunistic behaviour resulting from conflict of interests. Governance mechanisms differ in terms of costs and benefits, and these costs and benefits likely vary across firms, resulting in governance structures with different compositions and effects (Agrawal and Knoeber, 1996; Watts, 2006; Boone et al., 2007; McKnight and Weir, 2009). Thus, properly structured corporate governance mechanisms are expected to provide effective monitoring of management in the financial reporting process. The extant literature also suggests that ownership structure may also significantly influence firm accounting, affecting the quality of accounting information (Shleifer and Vishny, 1986; Morck et al., 1988).

Accounting conservatism serves as a mechanism to improve contracting efficiency, mitigate information asymmetry, and reduce the agency costs of firms (Holthausen and Watts, 2001; Ahmed and Duellman, 2007; LaFond and Watts, 2008). For example, Watts (2003a, b) explains that the demand for conservative accounting comes from the contracting role of accounting. LaFond and Watts (2008) provide evidence that conservatism is positively associated with the degree of information asymmetry. If conservative accounting is a vehicle to reduce agency costs, uncertainty and information asymmetry, it is expected that ownership concentration affects the level of conservative accounting. Therefore, examining the relation between ownership concentration and conservatism is potentially interesting.

\section{Ownership Concentration and Accounting Conservatism}

Large shareholders can be seen as potential controllers of equity agency problems as their increased shareholdings can give them a stronger incentive to monitor firm performance and managerial behaviour and influence firm management to protect their significant investments (Demsetz, 1983; Demsetz and Lehn, 1985; Shleifer and Vishny, 1986). Therefore, ownership concentration may reduce agency costs by increasing monitoring and alleviating the free-ride problem associated with ownership dispersion (Demsetz and Lehn, 1985; Shleifer and Vishny, 1986, 1997). Additionally, large shareholders have greater influence on managers, either due to their presence on the board of directors or their threat of disciplinary exist (Edmans and Manso, 2011). Thus, as concentration ownership increases, agency costs may be reduced by increasing monitoring. Therefore, if concentration ownership is a signal of monitoring effectiveness, then the higher the level of concentration ownership, the lower should be the likelihood of managers to use aggressive (more conservative) accounting. In addition, conservatism can help shareholders evaluate managerial investment decisions by reflecting bad news in a more timely fashion. Compared to small shareholders, large shareholders have both stronger incentives and greater means to influence managerial decisions and discipline managers upon receiving bad news (Chen et al., 2009). 
So, as concentration ownership increases, the demand for conservatism will increase. Chen et al. (2009) and Haw et al. (2012) find that conservatism is positively related to large shareholder ownership.

Therefore, ownership concentration is expected to monitor the financial information elaboration process by constraining executive's attempts to use aggressive (more conservative) accounting. Thus, we test the following hypothesis:

Hypothesis (H1): Ownership concentration in the firm is positively related to accounting conservatism.

\section{Variable measurement and research design}

\subsection{Measuring ownership concentration}

Portuguese listed firms need to disclose the ownership levels of shareholdings in excess of $2 \%$. Thus, ownership concentration (Concentration) is calculated as the proportion of stocks owned by shareholders who own at least $2 \%$ of the common stock of the company.

\subsection{Measuring accounting conservatism}

Following previous studies, we use a market-value based proxy to measure accounting conservatism (e.g., Givoly and Hayn, 2000; Ahmed et al., 2002; Zhang, 2007; Beatty et al., 2008; Hamdan et al., 2012). The market-value based measure of conservatism, Conservatism, is the market-to-book ratio. "Intuitively, conservative accounting results in reducing book values relative to market values" (Ahmad and Duellman, 2011, p. 616). As conservatism results in understating book value of equity relative to market value of equity, firms using conservative accounting should have higher market-to-book ratios.

\subsection{Control variables}

Given that the ownership concentrationis not the sole factors affecting accounting conservatism, we also evaluate the association between ownership structure and accounting conservatism, after controlling for the impact of other relevant variables. Several control variables are introduced to isolate other factors that may be influence managers' accounting conservatism. Previous studies suggest that audit committee (Audit), stock options (Options), leverage (Lev) and political costs (Size) are associated with accounting conservatism (Ahmed et al., 2002; Ahmed and Duellman, 2007; LaFond and Roychowdhury, 2008; Chen et al., 2009; Shuto and Takada, 2010; Ahmed and Henry, 2012; Wistawan et al., 2015).

Among the specific committees that can be created within boards of directors, the audit committee (Audit) has been considered as having a very important role within the governance structure. Accounting conservatism is considered an important characteristic of high-quality accounting information (Basu, 1997; Watts, 2003a; Xu and Lu, 2008). Consequently, it is expected that audit committees encourage conservative accounting approaches resulting in reliable accounting information. Krishnan and Visvanathan (2008), Ahmed and Henry (2012) and Wistawan et al. (2015) find that the existence of an audit committee is related to more conservative accounting.

Stock Options provide incentives for executives to take actions that increase share prices and consequently shareholders wealth. Theoretically, this would improve the alignment of management and shareholders' interests and therefore reduce agency costs, since stock options provide a direct link between executive utility level and shareholder wealth. For example, Hanlon et al. (2003) and Kato et al. (2005) find a significant positive relationship between stock options and performance. However, while executive stock options align managers' interest with those of the shareholders, they may also have some dysfunctional effects (Hall and Murphy, 2002, 2003). In practice, stock options may produce manager-shareholder conflicts (Jensen, 2005). For example, Melle-Hernández (2005), Kanagaretnam et al. (2009) and Alves (2011) find a negative relationship between stock options and firm performance. Empirical studies also find evidence that managers overstate earnings to maximize their stock-based compensation (e.g. Beneish, 1999; Safdar, 2003). The upward bias introduced by managers will lead to compensation overpayments, thereby reducing the stock values of shareholders. Shareholders, therefore, demand conservative accounting to offset this upward bias. In this vein, Jeong and Kim (2013) find that the CEOs with more equity-based compensation show more conservative behaviour.

Firms with high levels of leverage tend to have greater debt holders and shareholders conflicts (Ahmed and Duellman, 2007). Watts (2003a) argues that conservatism is an important feature of financial reporting in ensuring efficient contracting between shareholders and debt holders. Kothari et al. (2010) further argue that the demand for credible financial information from shareholders and debt holders leads to conservatism. Literature suggests that the degree of conservatism in financial reports is associated with the extent of the agency problem that arises from debt financing (Ahmed et al., 2002; Zhang, 2008). For example, Shuto and Takada (2010), Sun and Lin (2011), Ahmed and Henry (2012) and Cullinan et al. (2012) find that firms with higher leverage are more conservative in their financial reporting. 
Larger firms may face greater political costs relative to small firms' due to higher analyst following and investor scrutiny, which induces them to use more conservative accounting (Watts and Zimmerman, 1978, 1986). Consequently, the political cost (size) hypothesis suggests that large firms are more conservative accounting in order to reduce the probability of adverse impact from political exposure. Ahmed et al. (2002) and Sun and Lin (2011) find that large firms are more conservative in accounting choices.

\subsection{Regression model}

We evaluate the association between ownership concentration and accounting conservatism by estimating the following OLS regression:

Conservatism $_{i t}=\beta_{0}+\beta_{1}\left(\right.$ Concentration $\left._{i t}\right)+\beta_{2}\left(\right.$ Audit $\left._{i t}\right)+\beta_{3}\left(\right.$ Options $\left._{i t}\right)+\beta_{4}\left(\right.$ Leverage $\left._{i t}\right)+\beta_{5}\left(\right.$ Size $\left._{i t}\right)+\varepsilon_{\mathrm{it}}(1)$

Where:

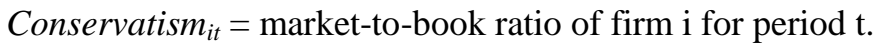

Concentration $_{i t}=$ proportion of stocks owned by shareholders who own at least $2 \%$ of the common stock of firm i for period $\mathrm{t}$.

Audit $_{i t}=$ dummy variable: 1 if the firm $\mathrm{i}$ for period $\mathrm{t}$ has an audit committee and 0 otherwise.

Options $_{i t}=$ dummy variable: 1 if the managers hold stock options and 0 otherwise.

Leverage $_{i t}=$ ratio between the book value of all liabilities and the total assets of firm $\mathrm{i}$ for period $\mathrm{t}$.

Size $_{i t}=\log$ arithm of market value of equity of firm i for period $\mathrm{t}$.

$\varepsilon_{\mathrm{it}}=$ residual term of firm i for period $\mathrm{t}$.

$\beta_{0}$ is a constant, $\beta_{1}$ to $\beta_{5}$ are the coefficients.

\subsection{Sample Selection}

The initial sample includes all companies whose stocks are listed in the main market, Euronext Lisbon. A total of 52, $50,48,51,51,51,50,49,52,51,49,48,50,50$ and 47 companies were listed at the year-end of 2002, 2003, 2004, 2005, 2006, 2007, 2008, 2009, 2010, 2011, 2012, 2013, 2014, 2015 and 2016 respectively (749 firm-year observations in total).

Foreign companies (49 in total) are excluded. Football companies (11 in total) are excluded, too. Companies not having shares listed in the previous year and companies whose shares were delisted in the following year are also excluded (220 in total). Companies (10 in total) with missing data are also excluded. Financial companies (69 in total) are excluded, too. As a result, the final sample size is 26 non-financial companies per year and, thus, 390 observations in total. This reduced number of observations may influence some results. Nevertheless, this limitation is an immediate consequence of the small size of the Portuguese stock market. Information on ownership concentration, total equity, audit committee, stock options and leverage are collected from the Annual Report and Corporate Governance Report. Both Annual Report and Corporate Governance Report are available on-line at www.cmvm.pt. We obtain stock price data from the Euronext Lisbon, which allows measuring the market value of equity.

\section{Results and discussion}

\subsection{Descriptive statistics}

Table 1 presents the sample descriptive statistics for the variables used in this research.Spearman correlations between the explanatory variables are documented in Table 2.

Table 1 - Summary of Descriptive Statistics Number of observations: 390; Period: 2002-2016

\begin{tabular}{lcccc}
\hline & Mean & Median & Min. & Max. \\
\hline Conservatism & 1.211 & 0.851 & -12.980 & 28.256 \\
Concentration & 0.734 & 0.769 & 0.085 & 0.988 \\
Audit & 0.360 & 1.000 & 0.000 & 1.000 \\
Options & 0.170 & 0.000 & 0.000 & 1.000 \\
Leverage & 0.775 & 0.729 & 0.062 & 4.148 \\
Size & 19.910 & 18.743 & 12.429 & 23.517 \\
\hline
\end{tabular}

Conservatism is the market-to-book ratio; Concentration represents the proportion of stocks owned by shareholders who own at least $2 \%$ of the common stock; Auditdummy variable which takes a value 1 if the firm has an audit committee and 0 otherwise; Optionsdummy variable which takes a value 1 if the managers hold stock options and 0 otherwise; Leverage represents the ratio between the book value of all liabilities and the total assets; Size represents the firm's size. 
Table 2 - Pearson Correlation Coefficients Matrix

\begin{tabular}{|c|cccc|}
\hline & Conservatism & Concentration & Leverage & Size \\
\hline Conservatism & 1 & & & \\
Concentration & $0.324^{* *}$ & 1 & & \\
Leverage & 0.021 & $-0.124^{*}$ & & \\
Size & $0.140 * *$ & -0.032 & $-0.155^{* *}$ & 1 \\
\hline
\end{tabular}

Conservatism is the market-to-book ratio; Concentration represents the proportion of stocks owned by shareholders who own at least $2 \%$ of the common stock; Leverage represents the ratio between the book value of all liabilities and the total assets; Size represents the firm's size.

** Correlation is significant at the 0.01 level (2-tailed); * Correlation is significant at the 0.05 level (2-tailed).

Table 1 shows that, while Conservatism, ranges between about -12.980 and 28.256, the mean and median are about 1.211 and 0.851 . The ownership concentration (Concentration) variable shows that, on average, that listed companies in Euronext Lisbon display a large degree of ownership concentration. In our sample, about $36 \%$ of companies have an audit committee (Audit). Table 1 shows that about $17 \%$ of companies attributed executive stock options (Options). Leverage variable represents on average 0.775 of the total assets of the company (with a median of 0.729 ). The mean of firm size (Size) is about EUR 980 million with a minimum of EUR 250 thousand and a maximum of EUR 16.345 million.

The analysis of Table 2 shows that there are some significant correlations between the variables. Concentration is positively related with Conservatism, suggesting that firms with higher ownership concentration adopt more conservative accounting. Size is positively correlated with Conservatism, suggesting that large firms have greater conservatism accounting activity. Size is negatively associated with Leverage, suggesting that larger firms have lower leverage constraint levels. A negative correlation between Leverage and Concentration indicates that firms with high leverage have higher ownership concentration. Correlation coefficients are, in general, low (below the 0.9 threshold) (Tabachnick and Fidell, 2001), suggesting the absence of serious statistical problems related with multicollinearity.

\subsection{Regression results}

Table 3 presents OLS regression estimates for the equation 1 developed in section three.

Table 3 - OLS Regression results

Number of observations: 390, Period: 2002-2016

\begin{tabular}{l|c|c}
\hline \multicolumn{1}{c|}{ Dependent variable } & \multicolumn{2}{c}{ Conservatism } \\
\hline \multicolumn{1}{c}{$\begin{array}{c}\text { Independent } \\
\text { variables }\end{array}$} & Coef. & t test \\
\hline Constant & 0.730 & 0.632 \\
Concentration & 2.416 & $1.836^{*}$ \\
Audit & 0.777 & 0.844 \\
Options & -0.695 & -1.280 \\
Leverage & 0.478 & $3.766^{* * *}$ \\
Size & 0.502 & $4.023^{* * *}$ \\
\hline R-squared & \multicolumn{2}{|c}{$15.01 \%$} \\
Adjusted R-squared & \multicolumn{2}{|c}{$11.56 \%$} \\
F-statistic & $1.931^{* * *}$ \\
\hline
\end{tabular}

Conservatism is the market-to-book ratio; Concentration represents the proportion of stocks owned by shareholders who own at least $2 \%$ of the common stock; Auditdummy variable which takes a value 1 if the firm has an audit committee and 0 otherwise; Optionsdummy variable which takes a value 1 if the managers hold stock options and 0 otherwise; Leverage represents the ratio between the book value of all liabilities and the total assets; Size represents the firm's size.

*** Significant at the 1-percent level; ** Significant at the 5-percent level; * Significant at the 10-percent level.

Table 3 reports the results from equation (1) which examines the association between ownership concentration and accounting conservatism. 
As in Chen et al. (2009) and Haw et al. (2012) we find a positive relationship between ownership concentration and accounting conservatism, suggesting that conservatism is significantly higher for firms with higher ownership concentration. This result suggests that large shareholders increase the likelihood that the quality of financial statements will be better controlled and if not, corrective action will be taken. Thus, if large shareholders have incentive to monitor managerial behaviour, then the higher the ownership concentration, the lower should be the likelihood of managers to use aggressive (more conservative) accounting. Conservatism can also help large shareholders evaluate managerial investment decisions by reflecting bad news in a more timely fashion. In addition, if conservative financial reporting provides governance benefits, large shareholders are more likely to understand and value such benefits, and as a result, demand conservative accounting from managers.

Regarding the other variables, included as control variables, we find, a positive relationship between Leverage and accounting conservatism, suggesting, as in Shuto and Takada (2010), Sun and Lin (2011), Ahmed and Henry (2012) and Cullinan et al. (2012), that higher leverage adopt more conservatism accounting methods.

Finally, the results suggest that conservatism accounting is significantly higher for firms with greater political costs (Size), confirming the results ofAhmed et al. (2002), Sun and Lin (2011) and Cullinan et al. (2012). These results are consistent with the political cost hypothesis of Watts and Zimmerman (1978), which suggests that firms choose accounting methods that minimise reported current earnings to lower their public profile and avoid political scrutiny.

Results suggest no evidence that the existence of an audit committee directly influences the level of conservatism accounting. In addition, stock options do not appear also affect the levels of accounting conservatism.

Summing up, the results reveal that ownership concentrated firms have a more demand for conservative accounting. On the other hand, higher leverage and large firms have also a greater demand for conservative accounting.

\section{Sensitivity analyses}

To ensure the robustness of our results, we perform several sensitivity checks. The first sensitivity analysis tests the impact of using alternative definition for the conservatism variable on regression results. We use an accrual-based measure of conservatism proxy to measure accounting conservatism. In line with Givoly and Hayn (2000), Xu et al. (2012), Kim et al. (2013) and Alkurdi et al. (2017) the accrual-based measure of conservatism, is income operations plus depreciation less cash flows from operations deflated by average total assets, multiplied by negative one. Positive values of Conservatism indicate greater conservatism. According to Givoly and Hayn (2000), the intuition underlying this measure is that conservative accounting results in persistently negative accruals.

The results (not reported here) of the regression of equations (1) using alternative variable to measure Conservatism has implications on Concentration variable, which wins significance level (from $\mathrm{p}<0.10$ to $\mathrm{p}<0.05$ ). The Leverage variable lost significance level (from $\mathrm{p}<0.01$ to $\mathrm{p}<0.05$ ). The other results remain unchanged (at coefficient signal and significant level).

The next sensitivity analysis examines the effect of influential observations on results. Where outliers are found (namely in the variables Conservatism andLeverage), a winserization method is used to test the robustness of the results. Extreme values (defined as values that are more than three standard deviations away from the mean) are replaced by values that are exactly three standard deviations away from the mean. The results (not reported here) do not differ from results presented previously in table 3. Thus, the influential observations do not affect the results.

Overall, the several sensitivity analyses conducted largely corroborate the results presented in table 3 .

\section{Summary and Conclusions}

Literature suggest that ownership structure plays a role in accounting conservatism (Ahmed et al., 2007; LaFond and Roychowdhury, 2008; Chi et al., 2009; Kung et al., 2010; Shuto and Takada, 2010; Cullinan et al., 2012; Ramalingegowda and Yu, 2012).

Therefore, this paper explores the relation between a firm's ownership structure and its degree of conservatism, within the Portuguese capital market. The empirical findings suggest that the accounting conservatism practices of Portuguese listed firms are influenced by these firms' ownership structure. Specifically, our study shows that ownership concentration increases accounting conservatism, suggesting that there is a greater level of financial reporting conservatism when shareholders have the incentives and power to discipline the managers. So, the empirical results suggest that large shareholders may have strong incentives to implement conservative accounting to reduce potential litigation costs and agency costs. Moreover, the results also reveal that there is more accounting conservatism when leverage and political costs are high. 
The findings of this study make the following contributions. First, the results indicate that, on average, ownership concentration affects conservative accounting in Portuguese listed firms. Second, the findings are relevant for countries with an institutional environment (concentrated ownership) similar to that of Portugal. Third, investors may also benefit from the findings because they provide insight into the impact of ownership structure on conservative accounting and earnings quality. Really, investors may wish to consider how different ownership structures may help them to protect their equity interests, and reduce information asymmetry throughaccounting conservatism. Finally, the results could also be of interest to regulators in considering regulatory reforms which may engender greater transparency, and which may modify the relative power among management and large shareholders.

\section{Acknowledgement}

This work was financially supported by the research unit on Governance_ , Competitiveness and Public Policy (UID/CPO/04058/2019), funded by national funds through FCT - Fundação para a Ciência e a Tecnologia.

\section{References}

Agrawal, A., Knoeber, C., 1996, "Firm Performance and Mechanisms to Control Agency Problems Between Managers and Shareholders", Journal of Financial and Quantitative Analysis, Vol. 37, pp. 337-397.

Ahmed, A. S., Billings, B. K., Morton, R. M., Stanford-Harris, M., 2002, "The role of accounting conservatism in mitigating bondholder-shareholder conflicts over dividend policy and in reducing debt costs", The Accounting Review, Vol. 77, No. 4, pp. 867-890.

Ahmed, A. S., Duellman, S., 2007, "Accounting conservatism and board of directors characteristics: An empirical analysis", Journal of Accounting and Economics, Vol. 46, No. 2/3, pp. 411-437.

Ahmed, A. S., Duellman, S., 2011, "Evidence on the role of accounting conservatism in monitoring managers' investment decisions", Accounting \& Finance, Vol. 51, pp. 609-633.

Alkurdi, A., Al-Nimer, M., Dabaghia, M., 2017, "Accounting Conservatism and Ownership Structure Effect: Evidence from Industrial and Financial Jordanian Listed Companies”, International Journal of Economics and Financial Issues, Vol. 7, No. 2, pp. 608-619.

Alves, S., 2012, "Executive stock options and earnings management in the Portuguese listed companies", Spanish Accounting Review, Vol. 15, No. 2, pp. 211-235.

Ball, R., Shivakumar, L., 2006, "The role of accruals in asymmetrically timely gain and loss recognition", Journal of Accounting Research, Vol. 44, No. 2, pp. 207-242.

Basu, S., 1997, "The conservatism principle and the asymmetric timeliness of earnings", Journal of Accounting and Economics, Vol. 24, No. 1, pp. 3-37.

Basu, S., 2005, "Discussion of conditional and unconditional conservatism: concepts and modeling", Review of Accounting Studies, Vol. 10, No. 2/3, pp. 311-321.

Beatty, A., Weber, J., Yu, J., 2008, "Conservatism and debt", Journal of Accounting and Economics, Vol. 45, No. 2-3, pp.154-174.

Beneish, M. D., 1999, “The Detection of Earnings Manipulation”, Financial Analysts Journal, Vol. 55, No. 5, pp. 2436.

Boone, A. L., Field, L. C., Karpoff, J. H., Raheja, C. G., 2007, "The determinants of corporate board size and composition: An empirical analysis", Journal of Financial Economics, Vol. 84, No. 1, pp. 66-101.

Chen, S., Chen, X., Cheng, Q., Hutton, A., 2009, "Accounting conservatism and large shareholders: An empirical analysis", Working Paper.

Chi, W., Liu, C., Wang, T., 2009, "What affects accounting conservatism: A corporate governance perspective", Journal of Contemporary Accounting \& Economics, Vol. 5, pp. 47-59.

Cullinan, C. P., Wang, F., Wang, P., Zhang, J., 2012, "Ownership structure and accounting conservatism in China", Journal of International Accounting, Auditing and Taxation, Vol. 21, pp. 1-16.

Demsetz, H., Lehn, K., 1985, "The Structure of Corporate Ownership: Causes and Consequences", Journal of Political Economy, Vol. 6, No. 93, pp. 1155-1177.

Demsetz, H., 1983, "The Structure of Ownership and the Theory of the Firm", The Journal of Law \& Economics, Vol. 26, No. 2, pp. 375-390.

Edmans, A., Manso, G., 2011, "Governance Through Trading and Intervention: A Theory of Multiple Blockholders", The Review of Financial Studies, Vol. 24, No. 7, pp. 2395-2428.

Fama, E.F. 1980, “Agency Problems and the Theory of the Firm”, Journal of Political Economy, 88, 2: 288-307. 
Francis, B., Hasan, I., Wu, Q., 2013, "The Benefits of Conservatism Accounting to Shareholders: Evidence from the Financial Crisis", Accounting Horizons, Vol. 27, No. 2, pp. 319-346.

García Lara, J. M., Osma, B. G., Penalva, F., 2009, “Accounting conservatism and corporate governance”, Review of Accounting Studies, Vol. 14, pp. 161-201.

Givoly, D., Hayn, C., 2000, "The changing time-series properties of earnings, cash flows and accruals: Has financial reporting become more conservative?", Journal of Accounting and Economics, Vol. 29, No. 3, pp. 287-320.

Hall, B. J., Murphy, K. J., 2002, "Stock options for undiversified executives", Journal of Accounting and Economics, Vol. 33, No. 1, pp. 3-42.

Hall, B. J., Murphy, K. J., 2003, "The trouble with stock options", Journal of Economic Perspectives, Vol. 17, No. 3, pp. 49-70.

Hamdan, A. M. M., Kukrija, G., Awwad, B. S. A., Dergham, M. M., 2012, "The Auditing Quality and Accounting Conservatism", International Management Review, Vol. 8, No. 2, pp. 33-50.

Hanlon, M., Rajgopal, S., Shevlin, T., 2003, “Are executive stock options associated with future earnings?", Journal of Accounting and Economics, Vol. 36, No. 1-3, pp. 3-43.

Haw, I. M., Ho, S., Tong, J. Y., Zhang, F., 2012, "Complex Ownership Structures and Accounting Conservatism", Working Paper.

Holthausen, R. W., Watts, R. L., 2001, "The relevance of value-relevance literature for financial accounting standard setting", Journal of Accounting and Economics, Vol. 31, pp. 3-75.

Jensen, M. C., Meckling, W. H., 1976, "Theory of the Firm: Managerial Behavior, Agency and Ownership Structure", Journal of Financial Economics, Vol. 4, pp. 305-360.

Jensen, M., 2005, “Agency costs of overvalued equity", Financial Management, Vol. 34, No. 1, pp. 5-19.

Jeong, K., Kim, H., 2013, "Equity-Based Compensation to Outside Directors and Accounting Conservatism", The Journal of Applied Business Research, Vol. 29, No. 3, pp. 885-900.

Kanagaretnam, K., Mathieu, R., Ramanan, R., 2009, "Stock options grants, current operating performance and deferral of earnings", International Journal of Management, Vol. 26, No. 1, pp. 26-32.

Kato, H. K., Lemmon, M., Luo, M., Schallheim, J., 2005, "An empirical examination of the costs and benefits of executive stock options: Evidence from Japan”, Journal of Financial Economics, Vol. 78, No. 2, pp. 435-461.

Kim, Y., Li, S., Pan, C., Zuo, L., 2013, "The Role of Accounting Conservatism in the Equity Market: Evidence from Seasoned Equity Offerings", The Accounting Review, Vol. 88, No. 4, pp. 1327-1356.

Krishnan, G.V. and Visvanathan, G. (2008), "Does the SOX Definition of an Accounting Expert Matter? The Association between Audit Committee Directors' Accounting Expertise and Accounting Conservatism", Contemporary Accounting Research, Vol. 25, No. 3, pp. 827-858.

Kung, F. H., Cheng, C. L., James, K., 2010, "The Effects of Corporate Ownership Structure on Earnings Conservatism: Evidence from China", Asian Journal of Finance and Accounting, Vol. 2, No. 1, pp. 47-67.

Lafond, R., Roychowdhury, S., 2008, "Managerial Ownership and Accounting Conservatism", Journal of Accounting Research, Vol.46, pp. 101-135.

LaFond, R., Watts, R. L., 2008, “The information role of conservatism”, The Accounting Review, Vol. 83, pp. 447-478.

McKnight, P. J., Weir, C., 2009, "Agency costs, corporate governance mechanisms and ownership structure in large UK publicly quoted companies: A panel data analysis", The Quarterly Review of Economics and Finance, Vol. 49 , pp. 139-158.

Melle-Hernández, M., 2005, “Cómo valora el Mercado de valores español la adopción de planes de opciones sobre acciones para directivos y consejeros?”, Investigaciones Económicas, Vol. 29, No. 1, pp. 73-115.

Morck, R., Shleifer, A., Vishny, R. W., 1988, "Management ownership and market valuation - an empirical analysis", Journal of Financial Economics, Vol. 20, No. 1-2, pp. 293-315.

Parthasarathy, K., 2010, "Corporate Governance, Conservatism and the Agency Problem”, Unpublished PhD Thesis, University of Houston.

Ramalingegowda, S., Yu, Y., 2012, "Institutional ownership and conservatism”, Journal of Accounting and Economics, Vol. 53, pp. 98-114.

Ruch, G. W., Taylor, G., 2014, "The Effects of Accounting Conservatism on Financial Statements and Financial Statement Users: A Review of the Literature", Working Paper, University of Alabama.

Safdar, I., 2003, "Stock option exercise, earnings management, and abnormal stock returns", Working Paper, Simon School, University of Rochester.

Shleifer, A., Vishny, R. W., 1986, "Large shareholders and corporate control", Journal of Political Economy, Vol. 94, No. 3, pp. 461-488.

Shleifer, A., Vishny, R. W., 1997, “A survey of corporate governance”, Journal of Finance, Vol. 52, No. 2, pp. 737783. 
Shuto, A., Takada, T., 2010, "Managerial Ownership and Accounting Conservatism in Japan: A Test of Management", Journal of Business Finance and Accounting, Vol. 37, No. 7/8, pp. 815-840.

Sun, J., Liu, G., 2011, "The effect of analyst coverage on accounting conservatism”, Managerial Finance, Vol. 37, No. 1, pp. $5-20$.

Tabachnick, B. G., L. S. Fidell, 2001, Using Multivariate Statistics, Allyn e Bacon, New York.

Watts, R. L., Zimmerman, J., 1986, Positive accounting theory, Englewood Cliffs, Prentice-Hall, New Jersey.

Watts, R. L., Zimmerman, J., 1978, "Towards a positive theory of the determination of accounting standards", The Accounting Review, Vol. 53, No. 1, pp. 112-134.

Watts, R. L., 2003a, "Conservatism in accounting part I: Explanations and Implications", Accounting Horizons, Vol. 17, No. 3, pp. 207-221.

Watts, R. L., 2003b, "Conservatism in accounting part II: Evidence and Research Opportunities", Accounting Horizons, Vol. 17, No. 4, pp. 287-301.

Watts, R. L., 2006, "What has the invisible hand achieved?", Accounting and Business Research, Vol. 36, pp. 51-61.

Wistawan, M. A. P., Subroto, B., Ghofar, A., 2015, "The Characteristics Board of Directors, Family Ownership and Accounting Conservatism: Evidence from Family Public Firms in Indonesia", Research Journal of Finance and Accounting, Vol. 6, No. 22, pp. 113-121.

$\mathrm{Xu}$, J., Lu, C., 2008, “Accounting Conservatism: A study of market-level and firm level-explanatory factors”, China Journal of Accounting Research, Vol. 1, pp. 11-29.

Xu, X., Wang, X., Han, N., 2012, “Accounting conservatism, ultimate ownership and investment efficiency", China Finance Review International, Vol. 2, No. 1, pp. 53-77.

Zhang, F., 2007, “Accruals, Investment, Growth, and the Accrual Anomaly", The Accounting Review, Vol. 82, No. 5, pp. 1333-1363. 